EGU2020-3315, updated on 08 Dec 2020

https://doi.org/10.5194/egusphere-egu2020-3315

EGU General Assembly 2020

(c) Author(s) 2020. This work is distributed under

the Creative Commons Attribution 4.0 License.

\title{
Historical land degradation strongly influences soil geography - a case in Ethiopia's mountains
}

\author{
Jan Nyssen ${ }^{1}$, Sander Tielens ${ }^{2}$, Kassa Teka ${ }^{3}$, Mitiku Haile ${ }^{3}$, Amanuel Zenebe ${ }^{3,4}$, R. Neil Munro ${ }^{4}$, Jean \\ Poesen ${ }^{2}$, Stefaan Dondeyne ${ }^{1}$, Amaury Frankl ${ }^{1}$, Seppe Deckers ${ }^{2}$, and Alemtsehay Tsegay ${ }^{5}$ \\ ${ }^{1}$ Department of Geography, Ghent University, Ghent, Belgium (jan.nyssen@ugent.be) \\ ${ }^{2}$ Department of Earth and Environmental Sciences, KU Leuven, Leuven, Belgium \\ ${ }^{3}$ Department of Land Resources Management and Environmental Protection, Mekelle University, Mekelle, Ethiopia \\ ${ }^{4}$ Institute of Climate and Society, Mekelle University, Mekelle, Ethiopia \\ ${ }^{5}$ Department of Dryland Crop and Horticultural Sciences, Mekelle University, Mekelle, Ethiopia
}

Understanding the geographical distribution of soils is indispensable for policy and decision makers to achieve the goal of increasing agricultural production and reduce poverty, particularly in the Global South. The soilscapes of the Giba catchment (900-3300 m a.s.l.; $5133 \mathrm{~km}^{2}$ ) in northern Ethiopia were studied, in support of sustainable soil use and land management. Based on their morphologic, physical and chemical properties, 141 soil profile pits and 1381 additional augered profiles were classified according to the World Reference Base for soil resources. The dominant soil units are Leptosols (19\% coverage), Vertic Cambisols (14\%), Regosols and Cambisols (10\%), Skeletic and Leptic Cambisols and Regosols (9\%), Rendzic Leptosols (7\%), Calcaric and Calcic Vertisols (6\%), Chromic Luvisols (6\%) and Chromic and Pellic Vertisols (5\%). The soilscapes are best explained by the topography and parent material that are the major factors determining the geomorphic processes in the area. Besides these two factors, land cover that is strongly impacted by human activities, may not be overlooked. Except for the Vertisols and patchy Phaeozems that are stable since the Mid-Holocene, all other soil units in the study area are the result of profile truncation on the one hand, and colluviation more downslope on the other hand. In addition, due to three millennia of soil tillage, lynchets have been formed at many places along the slope, and rock fragments concentrated on the surface, leading to armouring that locally prevents deeper erosion. Our soil suitability study shows that currently, after thousands of years of agricultural land use and concomitant land degradation, a new dynamic equilibrium has come into existence in the soilscape, in which ca. $65 \%$ of the catchment remains suitable for agricultural production. 